\title{
Corrosion Inhibition Study of Al-Cu-Ni Alloy in Simulated Sea-Water Environment
}

\author{
S. M. Adams ${ }^{1}$, S. A. Yaro ${ }^{2}$, M. Abdulwahab ${ }^{2}$, O. B. Umaru ${ }^{3 *}$ \\ ${ }^{1}$ Department of Metallurgical Engineering, Kogi State Polytechnic, Lokoja, Nigeria. \\ ${ }^{2}$ Department of Metallurgical and Materials Engineering, Ahmadu Bello University, Zaria, Nigeria. \\ ${ }^{3}$ Department of Mechanical and Production Engineering, Abubakar Tafawa Balewa University, Bauchi, Nigeria.
}

\begin{abstract}
A study on the inhibition of Al-Cu-Ni alloy in simulated sea-water environment was investigated using Sodium Chromate as inhibitor. The inhibitor concentration was varied as control, 0.25, 0.5, 1.0, 1.5 and 2.0 Molar. Al-Cu-Ni alloy was sand cast into cylindrical bars of $20 \mathrm{~mm} \times 300 \mathrm{~mm}$ dimension. The corrosion of the sand-cast and treated alloys in $3.5 \mathrm{wt} \%$ sodium chloride solution at temperatures $30^{\circ} \mathrm{C}, 50^{\circ} \mathrm{C}$ and $70^{\circ} \mathrm{C}$ over $1-5 \mathrm{hrs}$ was evaluated using the weight loss method. It was observed that the corrosion rate of the treated alloys decreases with increase in inhibitor concentration. The decrease in corrosion rate on addition of the inhibitor can be attributed to the adsorption of the inhibitor onto the surface of the alloy. The attachment is by physical adsorption as the values of heat of adsorption were less than $-10 \mathrm{~kJ} / \mathrm{mol}$. The plots obtained were linear meaning that they obey the Langmuir and Temkin adsorption isotherms. The inhibition efficiency increases generally with increase in temperature and inhibitor concentration.
\end{abstract}

KEYWORDS: inhibition, simulated sea-water, corrosion, alloy, concentration, adsorption

[Received May 22 2014; Revised March 232015 \& May 21 2015; Accepted June 6 2015]

\section{INTRODUCTION}

Corrosion and its control is a problem of great importance to the engineering industry with the rapid multiplying use of metals, the increasing occurrence of corrosive environment and the depletion of suppliers of ores (William and Javad, 2006). Corrosion is responsible for colossal loss of materials occurring everywhere and every moment involving billions of naira annually (Vijendra, 2009). Corrosion costs in the industrialized countries amount to about $4 \%$ of the gross national product. These include the cost, which can arise in the form of corrosion protection measures, through replacement of corrosion-damaged parts or through different effects deriving from corrosions, such as shut-down of production or accidents which lead to injuries or damage to property and occasional loss of lives (Einar, 1989).

As a consequence of the economics of production, environmental impact and ecological factors, it is becoming increasingly important to consider the "cradle-to-grave" life cycle of light alloy materials relative to the overall manufacturing process. This utmost necessitated the recent increase in research of the behaviour of $\mathrm{Al}$ alloys and other light metals subjected to different environments (Idenyi et al, 2009; Abdulwahab et al, 2011).

Inhibitors can be considered as a retarding catalyst and are used as a means of controlling and preventing corrosion. Inhibitor includes substances which on addition to the corrosive medium in very small amount retards the degradation of metals and can be used either in liquid media, gaseous media as well as to solid and semi-solid materials such as point file, packing material and protective greases (Kuznetsov, 2004).
In this work, the standard inhibitor (sodium chromate) has been found to be efficient for the $\mathrm{Al}-\mathrm{Cu}-\mathrm{Ni}$ alloy in reducing the corrosion rate by $65.7 \%$ and the mechanism of inhibition has been established from this result to be of physical adsorption.

\section{MATERIALS AND METHODS}

The materials used in this research include high purity aluminum and copper obtained from Northern Cable Company (NOCACO), Kaduna while the Nickel and sodium chromate (standard inhibitor) was obtained from a chemical shop in Zaria. Others include Kellers reagent as etchants were obtained from Metallurgical and Material Engineering Department of Ahmadu Bello University, Zaria. The equipment used for the heat treatment of the alloy was Muffle electrical resistance furnace with a capacity of $1200^{\circ} \mathrm{C}$, Metallurgical Microscope for microstructural analysis, Digital Weighing Balance for weight loss determination and digital multimeter Corrosion Bath to maintain the temperature of the system during the corrosion process.

$\mathrm{Al}-\mathrm{Cu}-\mathrm{Ni}$ alloy was produced by sand casting method in which the percentage of Copper, and Nickel were kept constant as shown in Table 1.

Table 1: Charge calculation of the produced alloy (wt \%).

\begin{tabular}{cccc}
\hline Element & Al & Cu & Ni \\
\hline Percentage & 94 & 4.0 & 2.0 \\
\hline
\end{tabular}

Melting of the alloy was done in a muffle resistance furnace that was allowed to heat up to $800^{\circ} \mathrm{C}$ for super heat to occur and then stirred thoroughly before pouring into the mould. The cast samples were prepared for corrosion test samples. The $\mathrm{Al}-\mathrm{Cu}-\mathrm{Ni}$ alloy samples were subjected to corrosion environment $(3.5 \mathrm{wt} \% \mathrm{NaCl}$ solution) under the 
influence of inhibitor (sodium chromate) at $30^{\circ} \mathrm{C}, 50^{\circ} \mathrm{C}$, and $70^{\circ} \mathrm{C}$ for $1-5 \mathrm{hrs}$. The corrosion was evaluated using weight loss technique. The standard expression for measurement of corrosion rate in Mils per Year (mpy) shown in eqn (1) was used (Fontana, 1987).

$$
m p y=\frac{534 W}{D A T}
$$

where

$\mathrm{W}=$ Weight loss $(\mathrm{g})$

$\mathrm{D}=$ Density of material $\left(\mathrm{g} / \mathrm{cm}^{3}\right)=2.7 \mathrm{~g} / \mathrm{cm}^{3}$

$\mathrm{T}=$ Time of exposure (hours)

$\mathrm{A}=$ Total surface area $\left(\mathrm{in}^{2}\right)$

The efficiency of an inhibitor I, can be expressed as in eqn (2).

$$
I=\frac{V_{0}-V_{i}}{V_{0}} \times 100
$$

where: $V o$ is the corrosion rate without inhibitor

$$
V_{i} \text { is the corrosion rate with inhibitor }
$$

The values of activation energy of inhibition $\left(E_{a}\right)$ in eqn (3) were calculated using the Arrhending equation (Nnanna et al, 2010).

$$
\log \frac{r_{1}}{r_{2}}=\frac{E a}{2.303 R}\left[\frac{1}{T_{1}}-\frac{1}{T_{2}}\right]
$$

where $r_{1}$ and $r_{2}$ are the corrosion rates in temperatures $T_{1}$ and $T_{2}$ respectively. $R$ is the universal gas constant $\left(8.314 \mathrm{~kg} / \mathrm{moy}^{-}\right.$ $\left.{ }^{1} / \mathrm{c}^{-1}\right)$. Free energy of adsorption and heat of adsorption were also calculated.

Optical microscope was used to analyse the various microstructures of the samples. Metallographic samples were sectioned from the as-cast samples and ground on grades of emery paper $(240,320,400$ and 600 grit-sizes using water as coolant. The ground samples were then polished with $1 \mu \mathrm{m}$ and $0.5 \mu \mathrm{m}$ sizes alumina powder suspension in distilled water. The polishing samples were then etched using Keller's reagent $\left(190 \mathrm{ml} \mathrm{H}_{2} \mathrm{O}+5 \mathrm{ml} \mathrm{HNO}_{3}+3 \mathrm{ml} \mathrm{HCl}+2 \mathrm{ml} \mathrm{HF}\right)$. The microstructures of the samples were obtained using an optical microscope with an in-built camera.

\section{RESULTS AND DISCUSSION}

The results of the corrosion rates of $\mathrm{Al}-\mathrm{Cu}-\mathrm{Ni}$ alloy at $30^{\circ} \mathrm{C}, 50^{\circ} \mathrm{C}$ and $70^{\circ} \mathrm{C}$ are shown in Tables $2-4$. In Tables 5-7 the calculated values of inhibition efficiency with inhibitor concentration of Al-Cu-Ni alloy at $30^{\circ} \mathrm{C}, 50^{\circ} \mathrm{C}$ and $70^{\circ} \mathrm{C}$ are presented. Tables 8-10 show the calculated values of the activation energy, free energy and heat of adsorption with inhibitor concentrations of Al-Cu-Ni alloy. Equally, Tables 11 - 13 show the values of thermodynamics and kinetic parameter. Figure 1 shows the microstructure of as-cast Al$\mathrm{Cu}-\mathrm{Ni}$ alloy. The structure in the figure consists of Aluminium solid solution matrix, (orange), and grain boundary consisting of interdendritic network of $\mathrm{CuAl}_{2}$ (dark) with grain boundary formations (x200).

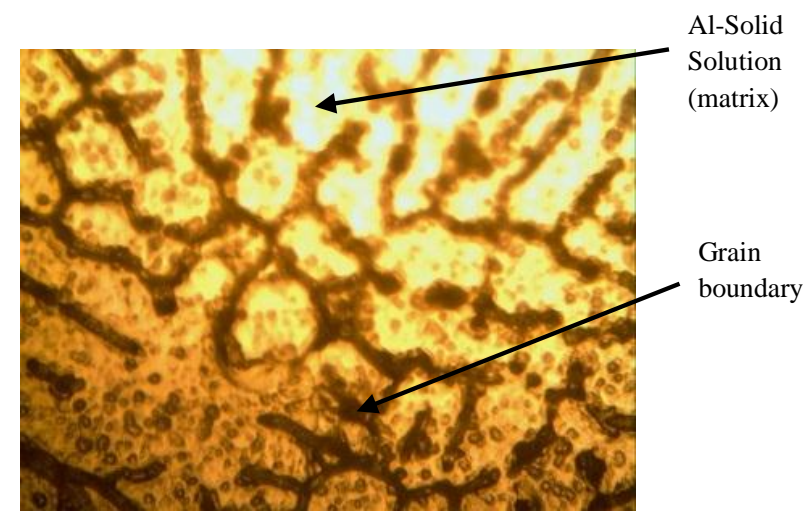

Figure 1: Micrograph of the as-cast Al-Cu-Ni alloy.

\section{A. Effect of Inhibitor Concentration on Corrosion Rate}

Inorganic inhibitors such as silicates, chromates, borates, etc, suppress the rate of corrosion by interfering between the anodic and cathodic reaction sites (Dara, 1986). This occurs as a result of the thin film formed on the surface of the alloy, which retards the corrosivity. The concentration of the inhibitor was varied $(0.25,0.5,1.0,1.5$ and $2.0 \mathrm{M})$ from 1$5 \mathrm{hrs}$ at $30^{\circ} \mathrm{C}, 50^{\circ} \mathrm{C}$ and $70^{\circ} \mathrm{C}$. Tables $2-4$ show the corrosion rate against inhibitor concentration of the cast $\mathrm{Al}-\mathrm{Cu}-\mathrm{Ni}$ alloy at various temperatures.

Table 2: Corrosion rates (mpy) of $\mathrm{Al}-\mathrm{Cu}-\mathrm{Ni}$ alloy at $30^{\circ} \mathrm{C}$.

\begin{tabular}{cccccc}
\hline $\begin{array}{c}\text { Inhibitor } \\
\text { Conc. (M) }\end{array}$ & \multicolumn{5}{c}{ Exposure time (hrs) } \\
\cline { 2 - 6 } Control & 1 & 2 & 3 & 4 & 5 \\
0.25 & 3.52 & 1.76 & 1.54 & 1.46 & 0.70 \\
0.5 & 3.20 & 1.68 & 1.32 & 1.29 & 0.64 \\
1.0 & 3.15 & 1.18 & 0.88 & 1.05 & 0.42 \\
1.5 & 3.02 & 1.54 & 0.50 & 0.71 & 0.39 \\
2.0 & 3.16 & 1.58 & 0.44 & 0.69 & 0.52 \\
\hline
\end{tabular}

Table 3: Corrosion rates (mpy) of $\mathrm{Al}-\mathrm{Cu}-\mathrm{Ni}$ alloy at $70^{\circ} \mathrm{C}$.

\begin{tabular}{lccccc}
\hline $\begin{array}{l}\text { Inhibitor } \\
\text { conc. (M) }\end{array}$ & \multicolumn{5}{c}{ Exposure time (hrs) } \\
\cline { 2 - 6 } Control & 1 & 2 & 3 & 4 & 5 \\
$\mathbf{0 . 2 5}$ & 1.93 & 1.56 & 1.32 & 1.24 & 0.99 \\
$\mathbf{0 . 5}$ & 1.67 & 1.40 & 1.10 & 1.00 & 0.61 \\
$\mathbf{1 . 0}$ & 1.21 & 1.15 & 1.08 & 0.92 & 0.88 \\
$\mathbf{1 . 5}$ & 0.76 & 0.94 & 0.88 & 0.74 & 0.52 \\
$\mathbf{2 . 0}$ & 0.41 & 0.52 & 0.44 & 0.35 & 0.21 \\
\hline
\end{tabular}


Table 4: Corrosion rates (mpy) of $\mathrm{Al}-\mathrm{Cu}-\mathrm{Ni}$ alloy at $70^{\circ} \mathrm{C}$.

\begin{tabular}{lccccc}
\hline $\begin{array}{l}\text { Inhibitor } \\
\text { conc.(M) }\end{array}$ & \multicolumn{5}{c}{ Exposure time (hrs) } \\
\cline { 2 - 6 } Control & 1 & 2 & 3 & 4 & 5 \\
0.25 & 1.93 & 1.56 & 1.32 & 1.24 & 0.99 \\
0.5 & 1.67 & 1.40 & 1.10 & 1.00 & 0.61 \\
1.0 & 0.76 & 1.15 & 1.08 & 0.92 & 0.88 \\
1.5 & 0.94 & 0.88 & 0.74 & 0.52 \\
2.0 & 0.41 & 0.52 & 0.44 & 0.35 & 0.21 \\
\hline
\end{tabular}

It was observed that the corrosion rate decreases generally with an increase in inhibitor concentration at $30^{\circ} \mathrm{C}, 50^{\circ} \mathrm{C}$ and $70^{\circ} \mathrm{C}$ for $1-5 \mathrm{hrs}$. These results show that the behaviour of the inhibitor in the environment resulted in the formation a protective layer on the metal surface thereby reducing the corrosion rate. This finding is in conformity with that reported by Ihebrodike et al (2010) and Nnanna et al, (2010).

\section{B. Effect of Inhibitor Concentration on Inhibition Efficiency}

The inhibitor efficiency increases with an increase in inhibitor concentration, tending to saturate at higher values of inhibitor concentration as shown in Tables 5-7.

Table 5: Inhibition efficiency of Al-Cu-Ni alloy (\%) at $30^{\circ} \mathrm{C}$.

\begin{tabular}{cccccc}
\hline $\begin{array}{c}\text { Inhibitor } \\
\text { concentration } \\
\text { (M) }\end{array}$ & $\mathbf{1 h r}$ & $\mathbf{2 h r s}$ & $\mathbf{3 h r s}$ & 4hrs & $\mathbf{5 h r s}$ \\
\hline $\mathbf{0 . 2 5}$ & 4.60 & 3.03 & 35.23 & 6.82 & 17.14 \\
$\mathbf{0 . 5}$ & 18.39 & 13.64 & 42.05 & 38.64 & 40.00 \\
$\mathbf{1 . 0}$ & 25.86 & 33.33 & 52.27 & 56.82 & 54.29 \\
$\mathbf{1 . 5}$ & 41.95 & 44.70 & 63.64 & 68.18 & 65.71 \\
$\mathbf{2 . 0}$ & 30.46 & 15.15 & 57.95 & 22.73 & 17.14 \\
\hline
\end{tabular}

Table 6: Inhibition efficiency of Al-Cu-Ni alloy (\%) at $50^{\circ} \mathrm{C}$.

\begin{tabular}{cccccc}
\hline $\begin{array}{c}\text { Inhibitor } \\
\text { concentration } \\
(\mathbf{M})\end{array}$ & $\mathbf{1 h r}$ & $\mathbf{2 h r s}$ & $\mathbf{3 h r s}$ & $\mathbf{4 h r s}$ & $\mathbf{5 h r s}$ \\
\hline 0.25 & 4.60 & 3.03 & 35.23 & 6.82 & 17.14 \\
0.5 & 18.39 & 13.64 & 42.05 & 38.64 & 40.00 \\
1.0 & 25.86 & 33.33 & 52.27 & 56.82 & 54.29 \\
1.5 & 41.95 & 44.70 & 63.64 & 68.18 & 65.71 \\
2.0 & 30.46 & 15.15 & 57.95 & 22.73 & 17.14 \\
\hline
\end{tabular}

Table 7: Inhibition efficiency of Al-Cu-Ni alloy (\%) at $70^{\circ} \mathrm{C}$.

\begin{tabular}{cccccc}
\hline $\begin{array}{c}\text { Inhibitor } \\
\text { concentration } \\
\text { (M) }\end{array}$ & 1hr & 2hrs & 3hrs & 4hrs & 5hrs \\
\hline 0.25 & 13.47 & 10.26 & 16.67 & 19.35 & 11.11 \\
0.5 & 37.31 & 26.28 & 18.18 & 25.81 & 38.38 \\
1.0 & 60.62 & 39.74 & 33.33 & 40.32 & 47.47 \\
1.5 & 73.06 & 71.79 & 68.94 & 71.77 & 78.79 \\
2.0 & 70.47 & 66.03 & 63.64 & 66.13 & 60.61 \\
\hline
\end{tabular}

This indicates that the effectiveness of the sodium chromate, as an inhibitor, in retarding the corrosion rate of cast $\mathrm{Al}-\mathrm{Cu}-\mathrm{Ni}$ alloy in the sodium chloride solution does not improve indefinitely with increase in inhibitor concentration. A point is reached at which an increase in the inhibitor concentration produces a small increase in the value of the inhibitor efficiency. This is attributed to the fact that at high temperature of $70^{\circ} \mathrm{C}$, the inhibitor constituent tends to dissociate and hence a drop in efficiency. A similar conclusion was reached in (Ameer et al, 2000; Callister, 1997).

\section{Effect of Inhibitor Concentration on Activation Efficiency}

The values of the activation energy of adsorption, $E_{a d s,}$ for inhibited systems are higher than those of uninhibited system indicating that the inhibitor retards the dissolution of aluminium making it more difficult for corrosion reaction to proceed based on equation of reaction in eqn (4).

$$
\mathrm{Al} \longrightarrow \mathrm{Al}^{3+}+3 \mathrm{e}^{-}
$$

The forward reaction is a corrosion process indicating anodic, while the reverse reaction is inhibiting action. The presence of inhibitor retards the dissolution of the Al thereby increasing the inhibiting action (Madugu and Abdulwahab, 2007; Aku et al, 2005). The negative values of free energy of adsorption obtained means that the adsorption process was spontaneous (Metal Handbook, 1979). The activation energy increases as the inhibitor concentration increases as shown in Tables 8 .

Table 8: Activation energy, Eads, (KJ/mol) of Al-Cu-Ni alloy at 1 and 5 hrs respectively.

\begin{tabular}{|c|c|c|c|c|c|c|}
\hline $\begin{array}{c}\text { Inhibitor } \\
\text { concentration } \\
\text { (M) }\end{array}$ & $\begin{array}{c}\text { Ea, } \\
1 \mathrm{hr} \\
30- \\
\text { 50 }^{\circ} \mathrm{C} \\
\end{array}$ & $\begin{array}{c}\text { Ea, 1hr } \\
50-70^{\circ} \mathrm{C}\end{array}$ & $\begin{array}{c}\text { Ea, } \\
1 \mathrm{hr} \\
30- \\
70^{\circ} \mathrm{C} \\
\end{array}$ & $\begin{array}{c}\text { Ea, } \\
5 \mathrm{hrs} \\
\mathbf{3 0 -} \\
\text { 50 }^{\circ} \mathrm{C}\end{array}$ & $\begin{array}{c}\text { Ea, } \\
5 \text { hrs } \\
50- \\
70^{\circ} \mathrm{C}\end{array}$ & $\begin{array}{c}\text { Ea, } \\
\text { 5hrs } \\
30- \\
70^{\circ} \mathrm{C}\end{array}$ \\
\hline 0.25 & -451 & 144 & -263 & -443 & 1441 & 152 \\
\hline 0.5 & -462 & 008 & -314 & -506 & 1031 & -21 \\
\hline 1.0 & -520 & -222 & -426 & -443 & 1986 & 324 \\
\hline 1.5 & -571 & -733 & -622 & -617 & 1634 & 93 \\
\hline 2.0 & -701 & -920 & -770 & -754 & 776 & -271 \\
\hline
\end{tabular}

D. Effect of Inhibitor Concentration on free Energy

The free energy was calculated and the values obtained in this work were all negatives suggesting that the adsorption of the inhibitor $\left(\mathrm{Na}_{2} \mathrm{CrO}_{4}\right)$ on to the surface of the alloy was a spontaneous process. The low negative values of free energy as shown in Table 9 indicated spontaneous adsorption of the inhibitor of molecules (Madugu and Abdulwahab, 2007) and the negative values also suggest a strong interaction of the inhibitor molecules on the alloy surface (Aku et al, 2005; Metal handbook, 1979).

\section{E. Effect of Inhibitor Concentration on Heat of Adsorption}

The heat of adsorption was calculated and the negative values obtained indicate inhibitor adsorption. From Table 10 
Table 9: Free energy of Al-Cu-Ni alloy at $1 \mathrm{hr}$ and $5 \mathrm{hrs}$, and at various temperatures.

\begin{tabular}{|c|c|c|c|c|c|c|}
\hline $\begin{array}{c}\text { Inhibitor } \\
\text { concentration } \\
\text { (M) }\end{array}$ & $\begin{array}{c}\Delta \mathbf{G}_{\text {ads. }} \\
1 \mathrm{hr}, \\
\mathbf{3 0}^{\circ} \mathrm{C}\end{array}$ & $\begin{array}{l}\Delta \mathbf{G}_{\text {ads. }} \\
5 \text { hrs, } \\
30^{\circ} \mathrm{C}\end{array}$ & $\begin{array}{c}\Delta \mathbf{G}_{\text {ads. }} \\
1 \mathrm{hr}, \\
\mathbf{5 0} \mathrm{C}\end{array}$ & $\begin{array}{l}\Delta \mathbf{G}_{\text {ads. }} \\
\mathbf{5 h r s ,} \\
\mathbf{5 0}^{\circ} \mathbf{C}\end{array}$ & $\begin{array}{c}\Delta \mathbf{G}_{\text {ads. }} \\
1 \mathrm{hr}, \\
\mathbf{7 0}^{\circ} \mathrm{C}\end{array}$ & $\begin{array}{l}\Delta \mathbf{G}_{\text {ads. }} \\
5 \mathrm{hrs}, \\
7 \mathbf{7 0}^{\circ} \mathrm{C}\end{array}$ \\
\hline 0.25 & -129.27 & -40.42 & -126.62 & -32.54 & -62.43 & -15.23 \\
\hline 0.5 & -20.21 & -3.00 & -15.18 & -5.00 & -7.32 & -37.73 \\
\hline 1.0 & -8.09 & -1.50 & -4.75 & -1.42 & -1.49 & -2.64 \\
\hline 1.5 & -4.10 & -0.85 & -1.53 & -0.57 & -0.58 & -0.42 \\
\hline 2.0 & -4.50 & -1.42 & -1.95 & -4.07 & -0.49 & -0.75 \\
\hline
\end{tabular}

the heat of adsorption decreases with increase in inhibitor concentration (Aku et al, 2005). Thermodynamic models can be used to explain the corrosion inhibition of sodium chromate on the alloy. The nature of adsorption depends on the values of $\Delta \mathrm{H}_{\mathrm{ads}}$. Thus if $\Delta \mathrm{H}_{\mathrm{ads}}<-10 \mathrm{~kJ} / \mathrm{mol}$., the adsorption is probably physical adsorption and if $\Delta \mathrm{H}_{\mathrm{ads}}>-10 \mathrm{~kJ} / \mathrm{mol}$., the adsorption is chemical (Asuke, 2008). The values obtained in this work were all less than $-10 \mathrm{KJ} / \mathrm{Mol}$. which supports the assertion that physical adsorption is proposed.

Table 10: Heat of adsorption, Hads, (kJ/mol) of Al-Cu-Ni alloy at 1 and 5 hrs.

\begin{tabular}{|c|c|c|c|c|c|c|}
\hline $\begin{array}{c}\text { Inhibitor } \\
\text { concentration } \\
\text { (M) }\end{array}$ & $\begin{array}{c}\mathbf{H}_{\text {ads., }} \\
\mathbf{1 h r} \\
\mathbf{3 0 -} \\
\mathbf{5 0}^{\circ} \mathrm{C}\end{array}$ & $\begin{array}{c}\mathbf{H}_{\text {ads. }} \\
1 \mathbf{h r} \\
50- \\
\mathbf{7 0}^{\circ} \mathrm{C} \\
\end{array}$ & $\begin{array}{c}\mathbf{H}_{\text {ads., }} \\
\mathbf{1 h r} \\
\mathbf{3 0 -} \\
\mathbf{7 0}^{\circ} \mathrm{C}\end{array}$ & $\begin{array}{c}\mathbf{H}_{\text {ads., }} \\
\text { 5hrs } \\
\text { 30- } \\
\text { 50 }^{\circ} \mathbf{C}\end{array}$ & $\begin{array}{c}\mathbf{H}_{\text {ads., }} \\
\mathbf{5 h r s} \\
\mathbf{5 0 -} \\
\mathbf{7 0}^{\circ} \mathrm{C}\end{array}$ & $\begin{array}{c}\mathbf{H}_{\text {ads., }} \\
\text { 5hrs } \\
\text { 30- } \\
\mathbf{7 0}^{\circ} \mathrm{C}\end{array}$ \\
\hline 0.25 & -332 & -1519 & -456 & -454 & -1595 & -796 \\
\hline 0.5 & -497 & -1432 & -430 & -612 & 2453 & 307 \\
\hline 1.0 & -652 & -2173 & -652 & -353 & 408 & 125 \\
\hline 1.5 & -930 & -1917 & -575 & -564 & -963 & -684 \\
\hline 2.0 & -842 & -2460 & -740 & -337 & -2959 & -457 \\
\hline
\end{tabular}

\section{F. Effect of Temperature on Corrosion Rate}

The analysis of the temperature dependence of inhibition efficiency as well as comparison of corrosion activation energies in the presence of inhibitor gives some insight into the possible mechanism of inhibitor adsorption (Nnanna et al, 2005). The effect of temperature on the corrosion rate of cast $\mathrm{Al}-\mathrm{Cu}-\mathrm{Ni}$ alloy with and without inhibitor addition was studied in the temperature range of $30^{\circ} \mathrm{C}, 50^{\circ} \mathrm{C}$ and $70^{\circ} \mathrm{C}$. From Table 11, it can be deduced that the corrosion rates decrease with increase in inhibitor concentration. This means that the adsorption process took place easily and the protective film becomes stable on the cast Al-Cu-Ni alloy. This is similar to the claim by Chetouani (2004).

\section{G. Effect of Temperature on Inhibition Efficiency and Activation Energy}

The inhibitory efficiency was found to increase with rise in temperature. This can be as a result of increase in the rate of chemical reaction with rise in temperature as suggested by (ASM, 1990). This also indicates that at higher temperature, there is likely desorption of the inhibitor from the surface (Tang. et al, 2003). The corrosion inhibition of sodium chromate could also be attributed to the presence of multiple bonds in inhibitor molecular structure as suggested by (Rahim and Kassim, 2008; Fontana, 1987) which enhanced adsorption of its molecules on the surface of the alloy.

The activation energy increases with increase in temperature as shown in Table 8 earlier discussed. This means that the mechanism of inhibition of the inhibitor is of physical adsorption on to the alloy surface (Nnanna et al, 2010).

\section{H. Evaluation of Adsorption Isotherm}

The degree of surface coverage shown in Tables 12 varied linearly with the logarithm of inhibitor concentration at $1 \mathrm{hr}$ and $5 \mathrm{hr}$ and at various temperatures, fitting a Temkin Isotherm, since it obeys the Temkin Isotherm and the mechanism of inhibition is by adsorption (Ekuma and Idenyi, 2006).

Table 12: Surface coverage $(\theta)$ and logarithm of inhibitor concentration $(\log c)$ at various temperatures (Temkin isotherm).

\begin{tabular}{|c|c|c|c|c|c|c|c|}
\hline $\begin{array}{l}\text { Inhibitor } \\
\text { conc. } \\
\text { (M) }\end{array}$ & Log.C & $\begin{array}{c}\theta_{1 \mathrm{hr},} \\
30^{\circ} \mathrm{C}\end{array}$ & $\begin{array}{l}\theta_{\text {5hrs,at }} \\
\mathbf{3 0}^{\circ} \mathbf{C}\end{array}$ & $\begin{array}{l}\theta_{\text {lhr,at, }} \\
\mathbf{5 0}^{\circ} \mathrm{C}\end{array}$ & $\begin{array}{l}\theta_{\text {5hrs,at }} \\
\mathbf{5 0}^{\circ} \mathbf{C}\end{array}$ & $\begin{array}{l}\theta_{1 \mathrm{hr}, \mathrm{at}}, \\
\mathbf{7 0}^{\circ} \mathrm{C}\end{array}$ & 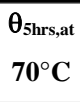 \\
\hline 0.25 & -0.6021 & 0.0284 & 0.085 & 0.046 & 0.1714 & 0.134 & 0.111 \\
\hline 0.5 & -0.3010 & 0.0909 & 0.400 & 0.183 & 0.4000 & 0.373 & 0.383 \\
\hline 1.0 & 0.0000 & 0.1051 & 0.400 & 0.258 & 0.5429 & 0.606 & 0.474 \\
\hline 1.5 & 0.1761 & 0.1420 & 0.442 & 0.419 & 0.6571 & 0.730 & 0.787 \\
\hline 2.0 & 0.3010 & 0.1022 & 0.257 & 0.304 & 0.1714 & 0.704 & 0.606 \\
\hline
\end{tabular}

The high negative values of the activation energy in this work indicate an efficient inhibiting action of the inhibitor (Ekuma and Idenyi, 2006). This indicated that the adsorption of sodium chromate on the surface of the Al-Cu-Ni alloy followed the Temkin Isotherm (Chetouani, 2004).

Table 11: Logarithms of corrosion rates and inverse of temperatures.

\begin{tabular}{|c|c|c|c|c|c|c|c|c|c|}
\hline $\begin{array}{c}\text { Inhibitor } \\
\text { concentration } \\
(\mathrm{M})\end{array}$ & $\begin{array}{c}\text { Log. } \\
\text { C.R at } \\
1 \mathrm{hr}\end{array}$ & $\begin{array}{c}\text { Log. } \\
\text { C.R at } \\
5 \text { hrs }\end{array}$ & $\begin{array}{l}1 / \mathrm{T} \text { at } \\
30^{\circ} \mathrm{C}\end{array}$ & $\begin{array}{c}\text { Log. } \\
\text { C.R } \\
\text { at } 1 \mathrm{hr}\end{array}$ & $\begin{array}{l}\text { Log. } \\
\text { C.R at } \\
5 \mathrm{hrs}\end{array}$ & $\begin{array}{c}1 / \mathrm{T} \text { at } \\
50^{\circ} \mathrm{C}\end{array}$ & $\begin{array}{c}\text { Log. } \\
\text { C.R } \\
\text { at } 1 \mathrm{hr}\end{array}$ & $\begin{array}{c}\text { Log. } \\
\text { C.R at } \\
\text { 5hrs }\end{array}$ & $\begin{array}{l}1 / \mathrm{T} \text { at } \\
70^{\circ} \mathrm{C}\end{array}$ \\
\hline 0.25 & 0.55 & -0.15 & 0.033 & 0.24 & -0.46 & 0.02 & 0.29 & -0.01 & 0.0143 \\
\hline 0.5 & 0.53 & -0.19 & 0.033 & 0.22 & -0.54 & 0.02 & 0.22 & -0.21 & 0.0143 \\
\hline 1.0 & 0.51 & -0.38 & 0.033 & 0.15 & -0.68 & 0.02 & 0.08 & -0.06 & 0.0143 \\
\hline 1.5 & 0.50 & -0.38 & 0.033 & 0.11 & -0.80 & 0.02 & -0.12 & -0.28 & 0.0143 \\
\hline 2.0 & 0.48 & -0.41 & 0.033 & 0.01 & -0.92 & 0.02 & -0.28 & -0.68 & 0.0143 \\
\hline
\end{tabular}




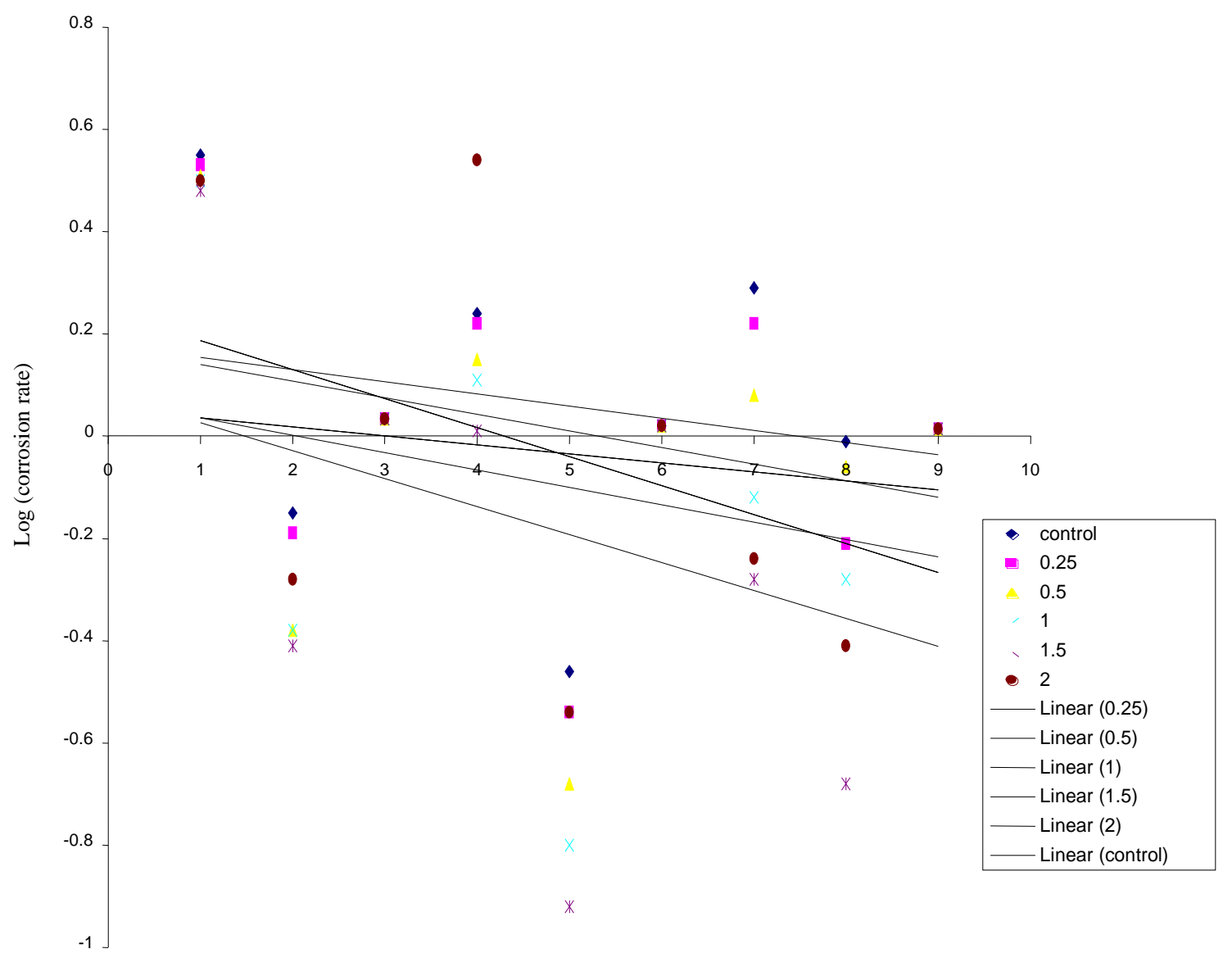

Figure 2: Arrhenius plot for the adsorption of sodium chromate on $\mathrm{Al}-\mathrm{Cu}-\mathrm{Ni}$ alloy in $3.5 \mathrm{wt} . \%$ sodium chloride solution.

\section{CONCLUSION}

Studies on the corrosion inhibition of Al-Cu-Ni alloy in simulated sea-water environment were investigated by varying the concentrations of Sodium Chromate as inhibitor and temperature of exposure to the corrosion medium i.e. $3.5 \mathrm{wt} \%$ sodium chloride solution. From the results obtained, it was concluded that the addition of inhibitor (sodium chromate) to the cast alloy show significant effect on the corrosion resistance of the alloy. The resistance of the alloy to corrosion increases with an increase in the concentration of the inhibitor. Secondly, the inhibitor efficiency of $\mathrm{Al}-\mathrm{Cu}-\mathrm{Ni}$ alloy in $3.5 \mathrm{wt} \%$ sodium chloride solution at $30^{\circ} \mathrm{C}, 50^{\circ} \mathrm{C}$ and $70^{\circ} \mathrm{C}$ increases with increase in temperature and that sodium chromate is an effective corrosion inhibitor for $\mathrm{Al}-\mathrm{Cu}-\mathrm{Ni}$ alloy in the examined environment.

\section{REFERENCES}

Abdulwahab, M., Madugu, I.A., Yaro, S.A., Popoola, A.P.I. (2011). Degradation Behaviour of High Chomium Sodium-Modified A356.0-Type Al-Si-Mg Alloy in Simulated Seawater Environment. Journal of Minerals and Materials Characterization and Engineering, 10(6): 535-551.

Aku, S. Y.: Oloche, O. B. and Yawas, D. S., (2005). Investigation of Non-Toxic Plant Extracts (Acacia Nilotica pods and KhayaSenegaleasis) as corrosion inhibitors of low carbon steel in $\mathrm{HCl}$ picking solution. Journal of Corrosion Science and technology, 3: $128-133$.

Ameer, M. A.: E. Khamis, G. Al-Sanani. (2000). Adsoption Studies of the Effect of Thiosemicarbazides on the Corrosion of Steel in Phosphoric Acid. Adsorption science Technology, 18(6): 177-194.

ASM Handbook (1990). Properties and Selection of non-ferrous Alloys and special purpose materials, (2): 21-22.

Asuke F. (2008). Corrosion Characteristics of $\mathrm{Al}-\mathrm{Si} / \mathrm{SiC}$ Composite in Sodium Hydroxide Solution using Propagyl and Palmwine as Inhibitors. Unpublished M.Eng Thesis. Department of Metallurgical and Materials Engineering. Ahmadu Bello University, Zaria-Nigeria.

Callister. W. D. (1997). Material science and engineering. New York. John Wiley and Sons Inc. $4^{\text {th }}$ edition.

Chetouani, A; Hammouti, B., and Benkaddour, M. (2004). Corrosion inhibition of iron in $\mathrm{HCl}$ acid solution by Jojoba Oil, Pigment and Resin Technology, 33(1): 26 - 31.

Dara. S. S. (1986). A textbook of engineering chemistry. Chand and company limited. New Delhi, India.

Einar. M. (1989). Basic Corrosion Technology for scientists and engineers. Ellis Horwood Limited, 12(9): 1314.

Ekuma. C.E and Idenyi. N. E. (2006). Inhibition characteristics of brine on the corrosion susceptibility of Al- 
Zn alloy systems. Journal of applied sciences, Pakistan, 6(8): 1751- 1770 .

Fontana. M. G. (1987). Corrosion engineering. $3^{\text {rd }}$ edition, McGraw-Hill Book Company. New York, 16(9): 282 $-287$.

Idenyi. N. E.: I.O. Owate and C.E. Okeke. (2009). Corrosion characterization of as-cast commercial Al-based alloy system in selected aqueous media. Chalcogenide Letters, 6(8): 367 - 376.

Ihebrodike. M. M.: A.U. Anthony.: B. O. kelechukwu and A. A. Gregory. (2010). The Inhibitive effect of solanummelongena leaf extract on the corrosion of aluminium in $\mathrm{H}_{2} \mathrm{SO}_{4}$.African Journal of Pure and Applied Chemistry, 4(8): $158-165$.

Kuznetsov. Y. F. (2004). Physicochemical aspects of metal corrosion inhibition in aqueous solutions. Russian Chemical reviews, 7(2): $75-87$.

Madugu. I. A. and Abdulwahab. M. (2007). The Mechanical Properties of As-cast Al-Si-Fe-Mn alloy. Nigerian Journal of Research and Production, 10 (2) $72-79$.

Metal Handbook (1979). Aluminium Casting alloys. Atlas of Microstructures of metal and alloys. ASM International. Ohio U.S.A.
Nnanna. L. A.: B. N. Onwagba.: I. M. Majeha, I. M., and Okeoma, K. B. (2010). Inhibition effects of some plant extracts on the acid corrosion of aluminium alloy. African Journal of Pure and Applied Chemistry, 4(1): 011 - 016.

Rahim. A. and Kassim. J. (2008). Recent Development on vegetal Tannins in Corrosion protection of Iron and steel. Material science, 1: 223 - 231.

Sharon. R. and Narain. S. (2006). Protection against corrosion an introduction to electrometallurgy. Standard Publishers Distributor. NaiSarak, Delhi 110006, India, 53-70

Tang. L.: M. Guannan. and L. Guangheng. (2003). The effect of neutral red on the corrosion inhibition of coldrolled steel in $1 \mathrm{M} \mathrm{HCl}$ acid. Corrosion science, 45: 2251 2262.

Vijendra. S. (2009). Physical Metallurgy Standard Publishers distributors. NaiSarak, Delhi - 110006: 696.

William. F. S. and Javad. H. (2006). Foundations of materials science and engineering 4th edition. McGraw Hill Higher Education, 345-738. 